\title{
Sengstaken-Blakemore tubes: a rescue system during liver transplantation
}

\author{
Antonio Cubisino $^{1,2}$, Fabrizio Panaro ${ }^{2}$ \\ ${ }^{1}$ Division of General, Minimally Invasive and Robotic Surgery, University of Illinois at Chicago, Chicago, IL, USA; ${ }^{2}$ Division of HBP Surgery and \\ Transplantation, Department of Surgery, Hôpital Saint Eloi, CHU-Montpellier, Montpellier, France \\ Correspondence to: Fabrizio Panaro, MD, PhD. HBP and Transplantation Surgery Unit, Department of Digestive Surgery and Transplantation, Saint- \\ Eloi Hospital, University of Montpellier, 80 avenue Augustin Fliche, 34295, Montpellier, France. Email: f-panaro@chu-montpellier.fr.
}

Submitted Aug 31, 2020. Accepted for publication Sep 25, 2021.

doi: $10.21037 / \mathrm{hbsn}-20-686$

View this article at: https://dx.doi.org/10.21037/hbsn-20-686

A 52-year-old woman has undergone liver transplantation (LT) owing to fulminant viral hepatitis, MELD 42.

The first cadaveric graft allocated was a large-for-size graft.

LT was performed with a piggyback side-to-side cavocaval anastomosis.

At the end of the procedure, the removal of the abdominal retractor produced, due to a narrow ribcage, a caval compression with liver congestion because of a reduced caval outflow.
A weak cardiac preload led to a decreased central venous pressure with hemodynamic instability.

To rescue the graft, as first described by Steinbruck et al. in 2010, we used two Blackmore tubes inflated with $300 \mathrm{cc}$ of sterile water each, placed into the retrohepatic, subdiaphragmatic space (Figure 1A,1B).

Blakemore tubes were progressively deflated from postoperative day 5 to day 10 when the tubes removal was possible.

A CT-scan was performed at postoperative day 10
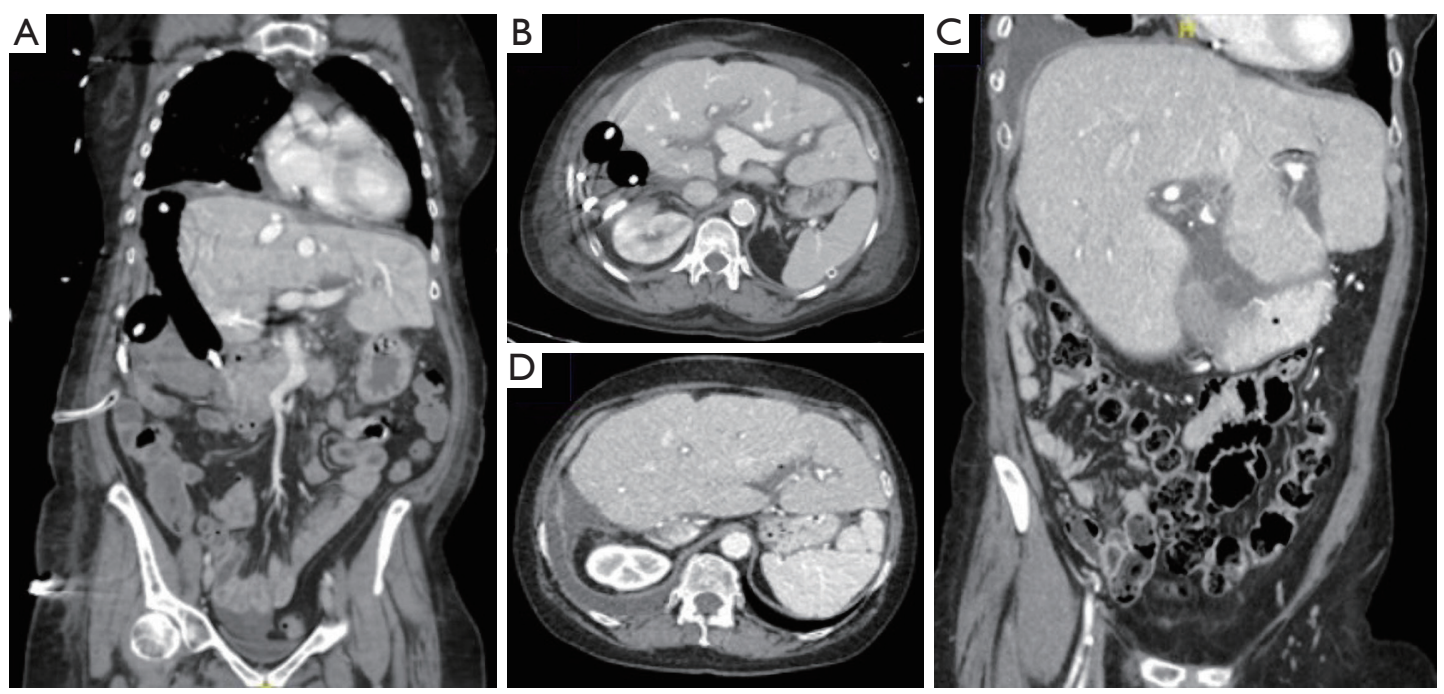

Figure 1 Postoperative CT scan image, at the postoperative day 2, showing the Blakemore tubes placed during liver transplantation to rescue the caval outflow (A,B). Control CT scan after Blakemore tubes removal at the postoperative day 10 (C,D). 
(Figure 1C,1D).

Postoperative Doppler-ultrasound confirmed the absence of caval obstruction and hepatic veins patency.

\section{Acknowledgments}

Funding: None.

\section{Footnote}

Provenance and Peer Review: This article was a standard submission to the journal. The article has undergone external peer review.

Conflicts of Interest: Both authors have completed the ICMJE uniform disclosure form (available at https://hbsn. amegroups.com/article/view/10.21037/hbsn-20-686/coif). FP serves as an unpaid editorial board member of the Hepatobiliary Surgery and Nutrition. The other author has no conflict of interest to declare.

Ethical Statement: The authors are accountable for all aspects of the work in ensuring that questions related to the accuracy or integrity of any part of the work are appropriately investigated and resolved. Written informed consent was obtained from the patient for publication of this manuscript and any accompanying images.

Open Access Statement: This is an Open Access article distributed in accordance with the Creative Commons Attribution-NonCommercial-NoDerivs 4.0 International License (CC BY-NC-ND 4.0), which permits the noncommercial replication and distribution of the article with the strict proviso that no changes or edits are made and the original work is properly cited (including links to both the formal publication through the relevant DOI and the license). See: https://creativecommons.org/licenses/by-nc-nd/4.0/.

Cite this article as: Cubisino A, Panaro F. SengstakenBlakemore tubes: a rescue system during liver transplantation. HepatoBiliary Surg Nutr 2022;11(1):171-172. doi: 10.21037/ hbsn-20-686 